\title{
The Impact of Subordinate Disability on Leader-Member Exchange Relationships
}

Author(s): Adrienne Colella and Arup Varma

Source: The Academy of Management Journal, Vol. 44, No. 2, (Apr., 2001), pp. 304-315 Published by: Academy of Management

Stable URL: http://www.jstor.org/stable/3069457

Accessed: 23/04/2008 11:25

Your use of the JSTOR archive indicates your acceptance of JSTOR's Terms and Conditions of Use, available at http://www.jstor.org/page/info/about/policies/terms.jsp. JSTOR's Terms and Conditions of Use provides, in part, that unless you have obtained prior permission, you may not download an entire issue of a journal or multiple copies of articles, and you may use content in the JSTOR archive only for your personal, non-commercial use.

Please contact the publisher regarding any further use of this work. Publisher contact information may be obtained at http://www.jstor.org/action/showPublisher?publisherCode=aom.

Each copy of any part of a JSTOR transmission must contain the same copyright notice that appears on the screen or printed page of such transmission.

JSTOR is a not-for-profit organization founded in 1995 to build trusted digital archives for scholarship. We enable the scholarly community to preserve their work and the materials they rely upon, and to build a common research platform that promotes the discovery and use of these resources. For more information about JSTOR, please contact support@jstor.org. 


\title{
THE IMPACT OF SUBORDINATE DISABILITY ON LEADER-MEMBER EXCHANGE RELATIONSHIPS
}

\author{
ADRIENNE COLELLA \\ Texas A\&M University \\ ARUP VARMA \\ Loyola University, Chicago
}

\begin{abstract}
An organizational simulation $(n=85$ ) and a field study (41 supervisors and 220 subordinates) were conducted to investigate the impact of subordinates' disability status on leader-member exchange (LMX) relationships. Both studies investigated how subordinate disability and ingratiation were related to LMX quality. As hypothesized, the interaction of disability and ingratiation affected LMX. Ingratiation had a stronger relationship to supervisors' LMX ratings when a subordinate had a disability. Implications of the results are discussed and suggestions for future research presented.
\end{abstract}

Since the passage of the Americans with Disabilities Act in 1990, there has been little improvement in employment rates and advancement for persons with disabilities (Blanck, 1997). Thus, it is imperative that researchers learn more about the work experiences of persons with disabilities. Although there is a fair amount of conceptual work on disability issues in the workplace (e.g., Colella, 1996; Klimoski \& Donahue, 1997; Stone \& Colella, 1996), little empirical work has been done in real workplace settings. One particularly crucial aspect of work experience for employees with disabilities is the relationship they develop with supervisors (Gates, 1993). Furthermore, research about people with disabilities has been criticized for ignoring the impact of their behavior (Fine \& Asch, 1988). In the study reported here, using both field and work simulation settings we empirically examined the impact of subordinate disability and behavior on subordinate-supervisor relationships. Both leadermember exchange (LMX) theory (Graen, 1976; Graen \& Cashman, 1975) and ambivalence response amplification theory (Katz \& Glass, 1979) were theoretical foundations. We begin with a general description of LMX theory.

Graen (1976) suggested that supervisors (leaders) develop different leader-member exchange relationships with each of their subordinates (mem-

The order of authorship is alphabetical. We would like to thank Angelo DeNisi, Ricky Griffin, and Bob Liden for their helpful comments on drafts. We also wish to thank Fran Yammarino for his help. The assistance of Lisa Brockenbraugh, Bob and Rose Cushing, Raj Lohani, Rajiv Mathur, and Greta Pennell in data collection is gratefully acknowledged. Portions of this research were funded by the New Jersey Developmental Disabilities Council. bers) and that the quality of this relationship is an important determinant of how each subordinate will be treated. The nature of the LMX relationship determines whether a subordinate fills an in-group or out-group member role. It has been shown that relationships developed in these dyads form quickly and tend to remain stable over time (e.g., Liden, Wayne, \& Stillwell, 1993). High-quality relationships are characterized by higher levels of supervisor support and guidance, higher levels of subordinate satisfaction and performance, and lower levels of subordinate turnover (e.g., Bauer \& Green, 1996; Liden \& Graen, 1980; Liden, Sparrowe, \& Wayne, 1997; Scandura, Graen, \& Novak, 1986).

We chose to examine the impact of disability on supervisor-subordinate relationships using the LMX model (Graen, 1976; Graen \& Cashman, 1975) for several reasons. First, this model provides a conceptual framework for understanding how individual characteristics (that is, disabilities) influence relationships with supervisors. This model also addresses subordinates' behavior, an issue that has been overlooked in the disability literature. Finally, the LMX model addresses dynamics important in the disability literature, including performance expectations and affect.

There are theoretical reasons to suggest that subordinate disability may influence the quality of LMX relationships. Dienesch and Liden (1986) postulated that three dimensions underlie LMX relationships: perceived contribution to an exchange in terms of work-oriented activities; loyalty; and mutual affect or liking. We propose that the disability status of a subordinate will influence a supervisor's LMX evaluations by influencing the supervisor's perceptions of contributions and affect. 
Because supervisor expectations about subordinate work contributions are important to leadermember exchange quality, expectations about future performance should also be important. Liden and colleagues (1993) found that supervisor expectations about subordinates' future performance were a better predictor of LMX quality than actual job performance. Raters tend to hold unduly low performance expectations for employees with disabilities (see Colella [1996] for a review). Also, stereotypes about people with disabilities include competence-related attributions such as helplessness and dependency (Fichten \& Amstel, 1986). These low performance expectations may lead to poor-quality LMX relationships.

Subordinate disability may also influence the quality of LMX relationships, with supervisors having less positive affect toward these subordinates because of the perception that these subordinates are different from themselves. According to the similarity attraction paradigm (Byrne, 1971), similarity between individuals increases their liking for each other and affects interactions and behavior as a result. Relational demography research has also demonstrated that employee demographic similarity is related to attraction (e.g., Tsui \& O'Reilly, 1989) and social integration (e.g., Jackson, Brett, Sessa, Cooper, Julin, \& Peyronnin, 1991). Research on the effect of supervisor-subordinate similarity on LMX relationships has shown that demographic dissimilarity (e.g., Turban \& Jones, 1988) and attitude and value dissimilarity (e.g., Engle \& Lord, 1997; Liden et al., 1993; Turban \& Jones, 1988) result in lower-quality LMX relationships.

Nondisabled people may perceive someone as different from themselves on the basis of the latter's disability status. Classic work on reactions to people with disabilities (Goffman, 1963; Jones et al., 1984) suggests that they are generally stigmatized and thus considered different. There is also Lerner's (1980) "just world hypothesis," which states that, for self-protective reasons, the nondisabled view those with disabilities as being responsible for the disabilities and, therefore, as different from themselves. Of course, the degree of stigmatization may vary as a function of the characteristics of a disability, such as its perceived cause (Stone \& Colella, 1996). In summary, nondisabled supervisors are likely to perceive subordinates with disabilities as dissimilar to themselves and so experience less positive affect. Also, supervisors may expect less contribution from subordinates with disabilities. Consequently, we hypothesize:

Hypothesis 1. Supervisors without disabilities will form lower-quality LMX relationships with subordinates with disabilities than they do with nondisabled subordinates.

Another postulate of LMX theory is that subordinate behavior affects LMX quality (Graen, 1976). Initial task performance has been demonstrated to be positively related to LMX quality (e.g., Wayne \& Ferris, 1990). The LMX literature (e.g., Wayne \& Ferris, 1990; Wayne \& Green, 1993) also suggests that subordinate upward influence behaviors, such as ingratiation, are an important factor. Ingratiation is defined as "a class of behaviors employed by a person to make himself/herself more attractive to another" (Wortman \& Linsenmeier, 1977: 134). Subordinate ingratiation has been demonstrated to influence supervisors' liking for subordinates (e.g., Wayne \& Ferris, 1990; Wayne \& Liden, 1995; Wayne, Liden, Graf, \& Ferris, 1997). In summary, we expect that subordinates' performance and ingratiation will be positively related to LMX quality.

Of more importance to the current study, we argue that performance and ingratiation will interact with disability in such a way that the impact of performance and ingratiation tactics on LMX quality will be more pronounced for subordinates with disabilities than for other subordinates. The conceptual reasoning for this argument lies in ambivalence response amplification (ARA) theory (Katz \& Glass, 1979). Specifically, Katz and Glass argued that nondisabled persons have ambivalent feelings toward persons with disabilities (or other stigmata). Feelings of aversion and hostility and of sympathy and compassion clash. For instance, a nondisabled person encountering a disabled person may see himself or herself as feeling friendly toward an unworthy person or hostile toward a less fortunate person. This ambivalence creates a conflict that, Katz and Glass (1979) argued, threatens self-esteem because people wish to perceive themselves as both judicious and humane. According to ambivalence response amplification theory, people resolve this conflict by strongly defending one type of reaction while strongly denying the other, a pattern resulting in extreme behavior toward the stigmatized person. The context of the situation determines the direction of the amplification. Contexts that are favorable toward the person with the disability will result in extreme positive responses, and unfavorable contexts will result in extreme negative responses. For example, encountering a person with a disability behaving positively would lead to more positive reactions than encountering a nondisabled person behaving in the same manner. Encountering a person with a disability behaving negatively would lead to more negative reactions. Gibbons, Stephan, Stephenson, and Petty (1980) found that 
subjects evaluated a confederate on crutches who performed well on an anagram task better than a nondisabled confederate who performed well. But when the confederate performed poorly, she was evaluated more negatively. In both cases, performance level had a stronger impact on the evaluations of a person with a disability. Because good subordinate performance and ingratiation should lead to higher-quality LMX relationships for all employees, we would expect this effect to be even more pronounced when subordinates have disabilities. That is, if supervisors react positively to high levels of performance or ingratiation, they will have even more positive reactions when the subordinates have disabilities. If subordinates with disabilities perform poorly or do not ingratiate, then supervisors are expected to react more negatively than they react to others. Thus, we propose:

Hypothesis 2. Subordinate performance and subordinate disability status will interact to influence $L M X$ quality in such a way that a higher performance level will have a stronger, positive impact on LMX relationships formed with subordinates with disabilities than on LMX relationships formed with nondisabled subordinates.

Hypothesis 3. Subordinate ingratiation and subordinate disability status will interact to influence $L M X$ quality, such that ingratiation will have a stronger positive impact on $L M X$ relationships for subordinates with disabilities than on those relationships formed with nondisabled subordinates.

Two studies were conducted to examine the impact of subordinate disability on the quality of LMX relationships-a work simulation experiment and a field study. We begin with the simulation that allowed us to manipulate actual subordinate performance, disability, and ingratiation.

\section{STUDY 1: WORK SIMULATION EXPERIMENT-METHODS}

In order to determine which type of disability to use in the simulation, we had pilot-study participants (12 subject matter experts and 11 people with disabilities) rate various disabilities on how suitable they would be for portrayal in the simulation experiment. The raters were provided with a detailed description of the research and a list of easily detectable physical disabilities and the implements we intended to use to portray each disability in the experimental setting (for instance, a wheel chair for paraplegia). Nineteen of the 23 raters ranked para- plegia as the most suitable disability for use in the experiment on the basis of ease of realistic presentation and the belief that paraplegia would not influence task performance. A paraplegic person in the pilot sample was able to do the task with no problems.

\section{Participants and Procedures}

To maintain experimental control in a realistic setting, we established a temporary organization. The university's Center for Management Development (CMD) was about to hire temporary workers to complete a bulk mailing project. We subcontracted for the project. Students from the same population from which we recruited workers would normally have been hired to perform the job. Thus, this was a real temporary job, and the materials the students prepared were actually mailed out. We recruited participants through an advertisement in the student newspaper that described the job as temporary and explained the exact duties. Eightyseven students responded to the ad, but data from only 85 participants ( 50 percent men; 82 percent white; average age of 23) could be used.

Study 1 involved a two-by-two-by-two betweensubjects design manipulating subordinate disability (paraplegia versus no disability), performance level (high versus low) and ingratiation (ingratiation versus no ingratiation). The dependent variable was the supervisor-perceived quality of LMX.

Participants reported one at a time to an assigned room in the CMD offices where they were met by an experimenter (one of the authors) and a confederate posing as another participant who had arrived a few minutes earlier. The experimenter introduced himself as working for the CMD. Participants were told that the CMD was interested in exploring better methods of sending out bulk mailings and studying the effects of having equally contributing team members act as supervisors. After they had completed the task, they filled out questionnaires.

Participants were told that they would work in two-person teams and that one employee would be the supervisor. Both supervisors and subordinates worked on the same task, attaching mailing labels to advertising brochures. Assignment to the supervisor role was allegedly based on a simple coin toss, but the participant was always selected as the supervisor and the confederate, as the subordinate. The participant and the confederate each worked on the task independently in the same room for 90 minutes. The experimenter sat in an adjoining room. After the task was over, the participant counted the number of brochures made by the sub- 
ordinate (the confederate). Then both filled out questionnaires.

Two paid actors were trained to portray the role of the subordinate. To control for gender effects, we had a male and a female confederate who each worked with same-sex participants. Preliminary analyses revealed no gender effects, in that results did not vary by gender, so data from both male and female dyads were combined for analyses. For each participant in the disability experimental condition, we depicted the confederate as paraplegic by having him or her use a wheel chair. A person who used a wheelchair regularly trained the confederates in its use, and other wheelchair users checked to make sure the confederates were behaving realistically. There was no indication of a temporary disability such as a broken leg. In the nondisabled condition, the same confederates walked and sat in a chair.

Ingratiation was manipulated by having confederates either engage or not engage in the four major ingratiation tactics presented by Jones and Wortman (1973). Specifically, the confederates were instructed and trained to use two statements from each category. We adapted these statements from the Measure of Ingratiatory Behavior in Organizational Settings (MIBOS) developed by Kumar and Beyerlein (1991). Examples of statements used in each category follow. For the category other enhancement, the confederate said "I'm glad you were picked as supervisor. I wouldn't know what to do!" For opinion conformity, she or he said "What is your major?" [response] "I think that is an excellent choice." For rendering favors, one statement was "If you would like, I could help you with this exercise after I am done." And for self-presentation, the confederate said "I am so excited. I just found out I got an 'A' on my independent study."

The ingratiation statements were made while the participants were working. In the no ingratiation condition, the confederate made neutral remarks such as "What is your major" or "So you're the supervisor." To control for other possible sources of similarity, the confederates also had scripted responses to questions that participants might ask. These responses were held constant across both confederates and conditions. For example, when asked, confederates always said they were nutrition science majors (this major was chosen because it was uncommon). Two participants were extremely talkative and inquisitive. Their data were dropped from the study.

We manipulated objective performance by providing normative information to the participants. Participants were unable to count how many brochures they or the confederate had made while working. Instead, the experimenter had the participant later count the number of brochures made by the confederate and then provided normative information. Participants were either told that the subordinate performed in the 85th percentile (high) or the 35th percentile (low) of others performing this job. The design of this study made it impossible to keep the confederate blind to the conditions, but she was not aware of the research hypotheses or the purpose of this research.

\section{Measures}

Leader-member exchange quality. We measured LMX quality with the seven-item LMX scale (Liden et al., 1993; Scandura et al., 1986; Scandura \& Graen, 1984), in which six items are rated from 1 , "strongly disagree," to 5, "strongly agree" and one item is rated on a different five-point scale. Items include questions on supervisor recognition of subordinate potential and supervisor understanding of subordinate job problems and needs. We summed item ratings to create an LMX score $(\alpha=.64)$.

Demographic variables. Data were collected about sex, age, race, employment (full-time/parttime/not employed), and disability as defined by the ADA.

Manipulation checks. We administered manipulation check questionnaires to participants after they had completed the experimental questionnaires. To check perceptions of disability status, we used a checklist of adjectives and asked each participant to indicate which words described the subordinate with whom he or she had worked. This list of adjectives included "paraplegic." The ingratiation manipulation check consisted of eight statements about the subordinate's behavior during the interaction, with two statements for each of the ingratiation techniques. Items rated on a five-point scale were summed into an ingratiation score $(\alpha=$ .74). We checked the performance manipulation by comparing performance ratings on an eight-item scale (range 1-40, $\alpha=.82$ ).

\section{STUDY 1: RESULTS}

All participants correctly identified subordinate disability status. Means on the ingratiation manipulation check (19.45 for ingratiation versus 9.41 for no ingratiation) varied significantly $\left(t_{83}=9.17, p<.01\right)$, indicating that this manipulation was successful. The performance level manipulation was also successful, given the difference between the ratings made by those in the high- $(\bar{x}=29.71)$ and low-performance $(\bar{x}=$ 18.76) experimental conditions. This difference 
was significant $\left(t_{84}=7.10, p<.01\right)$. Postexperiment interviews indicated that participants believed the reason they were recruited was to perform the mailing work and were surprised to learn that the subordinate was a confederate.

The results and cell means of a two-by-two-bytwo analysis of variance (ANOVA) conducted to test the hypotheses are presented in Table 1 . Hypothesis 1 , predicting a "main effect" for disability on LMX, was not supported. An underlying assumption of this study was that performance and ingratiation are positively related to LMX ratings. Performance and ingratiation both had significant main effects on LMX ratings.

Hypotheses 2 and 3 predict an interaction between disability and performance and ingratiation, respectively. Hypothesis 2 was not supported, as indicated by the nonsignificant effect of the performance-disability interaction. Hypothesis 3 was supported, since the interaction of ingratiation and disability was significant. An examination of the cell means indicates that the interaction was in the expected direction. The difference in the ratings made by supervisors who were and were not exposed to ingratiation was larger when the subordinates had the disability. Disabled subordinates were rated higher than nondisabled subordinates by the supervisors in the ingratiation experimental condition. There was no difference in ratings when the supervisors were in the no ingratiation condition.

\section{STUDY 1: DISCUSSION}

There was no main effect for disability and no effect on LMX ratings for the performance-disability interaction. However, as predicted, disability interacted with ingratiation to influence LMX ratings. When ingratiation was exhibited, participants reported a higher-quality leader-member exchange relationship with the disabled subordinate than with the nondisabled subordinate. To a lesser extent, in the no ingratiation condition, the subordinate with the disability received lower LMX ratings than did the nondisabled subordinate.

These findings suggest several issues that need to be addressed. First, the results suggest a weak response amplification pattern, with amplification more evident in the positive direction than in the negative direction. When subordinates ingratiated themselves, there was evidence of the "norm to be kind" (Hastorf, Northcraft, \& Picciotto, 1979); that is, participants made higher evaluations of a confederate with a disability than of a nondisabled confederate, with performance held constant. This finding coincides with other research examining ambivalence response amplification that has indicated general sympathy for persons with disabilities (e.g., Carver, Glass, Snyder, \& Katz, 1977). Gibbons and colleagues (1980) conducted a series of experiments to determine when the norm to be kind would prevail and concluded that such general sympathy effects will only be found when an interaction is of little personal importance to an

TABLE 1

ANOVA Results and Cell Means for Study $1^{\text {a }}$

\begin{tabular}{|c|c|c|c|c|c|c|}
\hline Effect & $\boldsymbol{F}$ & $\eta^{2}$ & Condition & $\boldsymbol{n}$ & LMX Cell Means & s.d. \\
\hline \multirow[t]{2}{*}{ Disability } & 0.26 & .00 & Disabled & 40 & 21.75 & 4.66 \\
\hline & & & Nondisabled & 45 & 21.13 & 5.86 \\
\hline \multirow[t]{2}{*}{ Performance } & $29.93^{* *}$ & .23 & Low performance & 43 & $18.83_{\mathrm{a}}$ & 4.13 \\
\hline & & & High performance & 42 & $24.07_{b}$ & 5.10 \\
\hline \multirow[t]{2}{*}{ Ingratiation } & $8.47^{*}$ & .06 & Ingratiation & 42 & $22.64_{b}$ & 5.40 \\
\hline & & & No ingratiation & 43 & $20.23_{a}$ & 4.99 \\
\hline \multirow[t]{4}{*}{ Performance $\times$ disability } & 2.17 & .00 & Low performance/disability & 20 & $19.85_{\mathrm{a}}$ & 4.05 \\
\hline & & & High performance/disability & 20 & $23.65_{b}$ & 4.53 \\
\hline & & & Low performance/no disability & 23 & $17.95_{a}$ & 4.08 \\
\hline & & & High performance/no disability & 22 & $24.45_{\mathrm{b}}$ & 5.64 \\
\hline \multirow[t]{4}{*}{ Ingratiation $\times$ disability } & $3.75^{\star}$ & .02 & Ingratiation/disability & 20 & $24.05_{c}$ & 4.13 \\
\hline & & & No ingratiation/disability & 20 & $19.45_{a}$ & 4.04 \\
\hline & & & Ingratiation/no disability & 22 & $21.36_{b}$ & 6.15 \\
\hline & & & No ingratiation/no disability & 23 & $20.91_{\mathrm{a}}$ & 5.69 \\
\hline
\end{tabular}

${ }^{a}$ Cell means with different subscripts are significantly different at $p<.05$.

The values of $F$ for the performance-ingratiation interaction (2.55) and for the three-way interaction of disability, performance, and ingratiation (0.10) were not statistically significant. Not reported here because they were neither hypothesized nor significant, cell means for these effects are available from the first author.

${ }^{\star} p<.05$

$\star \star p<.01$ 
evaluator. When a situation has important implications for the evaluator, then negative bias against persons with disabilities is most likely to manifest. Others have also found negative bias only in situations that were personally relevant to the actor (Colella, DeNisi, \& Varma, 1998; Stone \& Michaels, 1994). It may be that the brevity of the simulation and lack of consequences for participants created a situation in which negative bias was unlikely to surface. The brevity of the simulation may also explain the relatively low reliability of the LMX measure. Thus, this issue appeared to need to be examined in a situation more personally relevant to participants, as it was in the next study we report.

Second, the amplification effect was not found for performance. There are two potential reasons for the absence of an effect. One was that performance information in this study was so clear and its effect on leader-member exchange ratings was so strong that the performance information may have overridden any other information. Second, it may be that performance information is not related to reactions to the disability in question, paraplegia. We purposely used a disability that was unrelated to performing the job in question. On the other hand, ingratiation behaviors may have acted to contradict other, non-performance-related stereotypes. For example, one common stereotype is that people with physical disabilities are helpless and passive (Fichten \& Amstel, 1986). However, when participants were under the experimental ingratiation condition, the subordinate with the disability clearly offered to help the participant-a behavior that might be viewed as contrary to the helpless and passive stereotype. The ambivalence response amplification literature does not say much about what types of behaviors are likely to result in response amplification, yet our results suggest that different behaviors may have different effects.

Finally, one can reasonably question whether a 90-minute simulation is the correct context in which to assess LMX dynamics. However, theoretical and empirical work has demonstrated that LMX dynamics take place extremely early in relationships (e.g., Liden \& Graen, 1980; Liden et al., 1993) and can be observed in laboratory settings in situations lasting for as little as $\mathbf{3 0}$ minutes (Wayne \& Ferris, 1990). Liden and his coauthors (1993) explained this quick development in terms of cognitive information processing models that suggest that at the very beginning of relationships, supervisors cognitively categorize subordinates on the basis of salient characteristics (which would include disability and performance). Using this categorization, the leaders form expectations that influence the quality of subsequent leader-member interaction. Engle and Lord (1997) suggested that many variables thought to influence LMX relationships are likely to be influential from the very beginning of the relationships. Indeed, our short-term simulation should have been able to capture at least the early affective component of LMX relationships (Dienesch \& Liden, 1986; Liden \& Maslyn, 1998), since numerous studies have demonstrated that individuals do base affective reactions to others on relatively short-term interactions in laboratory settings (e.g., Huston \& Levinger, 1978). This is not to say that the lab is the best place to examine LMX relationships, but we can say that findings from the laboratory may generalize to field settings because they represent the very first encounters associated with developing LMX relationships. Our results suggest that these dynamics did take place, in that the LMX ratings were influenced by ingratiation, performance, and the disability-ingratiation interaction. Yet these results need to be replicated in real work dyads, which is the purpose of the second study.

\section{STUDY 2: CORRELATIONAL FIELD RESEARCH-METHODS}

Study 2 was a correlational field study in which we examined the relationship between subordinate disability and ratings of leader-member exchange quality. We collected both subordinate and supervisor perceptions of LMX quality and subordinate ingratiation. We were unable to obtain information on objective performance, so we were only able to test Hypothesis 1 (main effect for disability) and Hypothesis 3 (interaction effect of disability and ingratiation) from study 1 .

\section{Participants and Procedures}

In study 2, the unit of analysis was the supervisor-subordinate dyad; thus, the sample size was the number of dyads. Participants were 220 subordinates and 41 supervisors, each of whom had an average of 5 subordinates. Approximately 80 percent of the supervisors contacted agreed to participate. The response rate for subordinates is difficult to determine since they were contacted by their organizations. The average age of the subordinates was 35 years; 53 percent were male, 66 percent were white, and their average organizational tenure was 5 years and five months. The average age of the supervisors was 46 years; 72 percent were male, 57 percent were white, and their average organizational tenure was 11 years. Of the 220 subordinates, 32 reported that they had disabilities. These included learning disabilities, paraplegia, blindness, 
and hearing impairment. No supervisor reported a disability.

We needed to locate a significant number of dyads in which the subordinate had a disability. Four northeastern U.S. organizations of similar size and in similar lines of business (electronics/telecommunications) participated. Contact people in the human resource (HR) departments of these organizations gave out questionnaires to supervisorsubordinate dyads. They made sure that they sampled some dyads in which a subordinate had a known disability. The HR contacts indicated that the supervisors knew of all the disabilities. To protect the identity of participants but still match supervisor and subordinate data, we used a coding system. The surveys were sent to participants with a cover letter from the HR department that stated that this was a study about leadership. Participants were provided with a stamped addressed envelope so they could mail completed surveys directly back to us. Organizations did not have access to the raw data.

Only data from dyads where both the supervisor and subordinate participated were used. Subordinates completed a questionnaire assessing perceptions of LMX quality, their own ingratiation behavior, and demographic information. The questionnaire for supervisors assessed LMX quality ratings, subordinate ingratiation, and demographic information. Supervisors with more than one subordinate participating in the study completed one questionnaire for each subordinate.

\section{Measures}

Subordinate disability. Subordinates indicated on their questionnaires whether they had a disability and, if so, what type. This question was presented amidst other demographic questions at the end of the questionnaire. As noted, we determined from the appropriate organizational contact person that the supervisor of a given subordinate was aware that the person in question had a disability. We did not ask supervisors about the subordinates' disability status to avoid cuing them to the nature of this study.

Ingratiation. Kumar and Beyerlein's (1991) MIBOS questionnaire was used to measure perceptions of ingratiation (other enhancement, opinion conformity, rendering favors, and self-presentation). Two slightly different versions of the scale were created for supervisors and subordinates. The supervisor version included questions such as "Does the subordinate (in question) look for opportunities to admire you?" The subordinate version included questions such as "Do you look for opportunities to admire your supervisor?" Each scale contained 24 questions rated on a five-point scale $(1=$ "rarely" and 5 = "very often"). Item scores were summed to arrive at the ingratiation score. Cronbach alphas were .84 and .85 for supervisory and subordinate perceptions, respectively.

LMX quality. This variable was again measured with the seven-item LMX scale (Liden et al., 1993; Scandura et al., 1986; Scandura \& Graen, 1984). Again, item scores were summed to create an LMX score. We also collected information on perceptions of LMX quality from the subordinates to validate supervisory perceptions, using a modified version of the same seven-item supervisor LMX scale. Cronbach's alphas were greater than $\mathbf{8 0}$.

Demographic control variables. Supervisors and subordinates reported their age, sex, and race. We chose these variables because research has demonstrated that similarity on these characteristics is important in the development of work relationships (e.g., Tsui \& O'Reilly, 1989). We calculated relational demographic measures of age, race, and sex differences by squaring the difference between supervisor and subordinate scores on each of the three demographic variables (Tsui \& O'Reilly, 1989). Age difference was scored as a continuous value in terms of years. Sex and race differences were dichotomously scored so that 0 equaled no difference and 1 equaled a difference.

\section{STUDY 2: RESULTS}

Table 2 presents descriptive statistics and correlations among variables. Correlations between supervisor and subordinate ingratiation and LMX ratings ( $r$ 's $=.77$ and .52 , respectively) suggest agreement about the LMX relationship and subordinate ingratiation. The correlation between disability and ingratiation $(r=.30)$ suggests that subordinates with disabilities engaged in more ingratiation.

We conducted a within and between analysis (WABA) (e.g., Dansereau, Alutto, \& Yammarino, 1984; Yammarino \& Markham, 1992) to determine if there were significant supervisor effects on LMX ratings. We found a between-supervisors eta of .62 $\left(\eta_{\mathrm{B}}^{2}=.39\right)$ and a within-supervisor eta of $.78\left(\eta_{\mathrm{W}}^{2}=\right.$ .61). Thus, 61 percent of the variance in supervisor LMX ratings occurs within supervisors. Statistical $\left(F_{40,179}=2.84, p<.01\right)$ and practical tests $(\mathrm{E}=$ $\eta_{\mathrm{B}}^{2} / \eta_{\mathrm{W}}^{2}=.80$ ) indicate there was no significant supervisor effect. Thus, we did not control for supervisor effects in the following analyses.

Hierarchical regression was used to test hypotheses. The dependent variable was supervisor LMX ratings. Relational demography control variables 
TABLE 2

Descriptive Statistics, Correlations, and Scale Reliabilities, Study $\mathbf{2}^{\text {a }}$

\begin{tabular}{|c|c|c|c|c|c|c|c|c|c|c|c|c|c|}
\hline Variable & Mean & s.d. & 1 & 2 & 3 & 4 & $\mathbf{5}$ & 6 & 7 & 8 & $\mathbf{9}$ & 10 & 11 \\
\hline 1. Supervisor ingratiation & 69.37 & 22.79 & $(.84)$ & & & & & & & & & & \\
\hline 2. Subordinate ingratiation & 73.69 & 20.63 & $.77^{\star \star}$ & $(.85)$ & & & & & & & & & \\
\hline 4. Subordinate LMX & 26.16 & 4.74 & $.29 \star \star$ & $.30 * \star$ & $.52^{\star *}$ & $(.88)$ & & & & & & & \\
\hline 5. Disability ${ }^{\mathrm{b}}$ & 0.15 & 0.35 & $.29 * \star$ & $.30 * \star$ & -.02 & -.02 & & & & & & & \\
\hline 6. Organization 1 & 0.20 & 0.40 & $.19^{* *}$ & $.15^{*}$ & -.07 & -.00 & $.15^{\star}$ & & & & & & \\
\hline 9. Subordinate tenure & 64.08 & 55.43 & -.12 & $-.18^{\star *}$ & -.00 & -.06 & -.01 & -.10 & .08 & -.02 & & & \\
\hline 10. Age difference & 19.35 & 13.99 & -.06 & -.03 & -.00 & .02 & .03 & $.48^{\star \star}$ & -.09 & $-.14^{\star}$ & -.09 & & \\
\hline 11. Race difference & 0.47 & 0.50 & .11 & .07 & .06 & .02 & -.08 & .04 & $.19^{\star *}$ & -.03 & -.02 & .09 & \\
\hline 12. Sex difference & 0.65 & 0.48 & .10 & .13 & .09 & $.15^{*}$ & $-.13^{*}$ & $.31 * *$ & .00 & -.01 & -.05 & $.31 * *$ & .11 \\
\hline
\end{tabular}

${ }^{a}$ Coefficient alphas are in parentheses on the diagonal.

${ }^{\mathrm{b}}$ Coded 1 = disability, $\mathbf{0}=$ no disability.

${ }^{*} p<.05$

$\star * p<.01$

were entered into the model at the first step. Second, subordinate disability and subordinate ingratiation were added to the model. Subordinate ratings of ingratiation were used to avoid common method variance problems. Finally, the disabilityingratiation interaction was entered into the model. Table 3 presents the results of this analysis.

Hypothesis 1 was supported by a significant disability effect. The negative weight indicates that supervisors reported lower LMX quality for subordinates with disabilities. Hypothesis 3 was also supported, as evidenced by a significant disabilityby-ingratiation effect. In order to examine the form of this interaction, we plotted the regression equations for both disability conditions, as is shown in Figure 1. As predicted, the regression slope is much steeper for subordinates with disabilities, indicating that ingratiation had more of an impact on LMX ratings when subordinates had a disability than when they did not. We regressed LMX ratings on ingratiation (after controlling for the control variables) for the disabled and nondisabled groups separately. Ingratiation accounted for approximately 40 percent $(r=.63, p<.001)$ of the variance in LMX ratings for disabled subordinates and only about 10 percent $(r=.32, p<.001)$ of the variance in LMX ratings for nondisabled employees. The difference between these effects is significant (Fisher's $Z=5.18, p<.001$ ). To further examine the ingratiation-disability interaction, we compared the mean LMX ratings for subordinates with and without disabilities broken down by those who fell above the median ingratiation score (70) and those who fell below it. When ingratiation was high, the mean LMX rating for subordinates with disabilities (26.32) did not significantly differ from
TABLE 3

Results of Hierarchical Regression Analysis for Supervisor LMX Ratings, Subordinate Disability, and Ingratiation ${ }^{\mathrm{a}}$

\begin{tabular}{|c|c|c|}
\hline Variable & $\boldsymbol{b}$ & s.e. \\
\hline \multicolumn{3}{|l|}{ Step 1} \\
\hline Organization 1 & -2.52 & 1.02 \\
\hline Organization 2 & -0.58 & 0.93 \\
\hline Organization 3 & -0.47 & 0.77 \\
\hline Tenure & 0.01 & 0.01 \\
\hline Age difference & 0.02 & 0.02 \\
\hline Race difference & 0.36 & 0.59 \\
\hline Sex difference & 0.64 & 0.66 \\
\hline$R^{2}$ & \multicolumn{2}{|c|}{.02} \\
\hline \multicolumn{3}{|l|}{ Step 2} \\
\hline Disability $^{\mathrm{b}}$ & $-12.52^{\star \star}$ & 3.81 \\
\hline Ingratiation & $0.07^{\star *}$ & 0.02 \\
\hline$\Delta R^{2}$ & \multicolumn{2}{|c|}{$.15^{\star *}$} \\
\hline$R^{2}$ & \multicolumn{2}{|c|}{$.17^{\star *}$} \\
\hline \multicolumn{3}{|l|}{ Step 3} \\
\hline Disability $\times$ ingratiation & $0.15^{\star *}$ & 0.05 \\
\hline$\Delta R^{2}$ & \multicolumn{2}{|c|}{$.04 * *$} \\
\hline Total $R^{2}$ & \multicolumn{2}{|c|}{$.21 * *$} \\
\hline Total $F$ & \multicolumn{2}{|c|}{$5.38^{\star *}$} \\
\hline Intercept & \multicolumn{2}{|c|}{19.30} \\
\hline
\end{tabular}

${ }^{\text {a }}$ All $R^{2}$ values are adjusted.

${ }^{\mathrm{b}}$ Coded 1 = disability, $\mathbf{0}=$ no disability. ${ }^{\star *} p<.01$

the mean for subordinates without disabilities (26.97). When ingratiation was low, the mean LMX rating for disabled subordinates (20.71) was significantly $(t=5.04, p<.01)$ lower than the mean LMX 
FIGURE 1

\section{Effect of Disability-Ingratiation Interaction on LMX Ratings, Study 2}

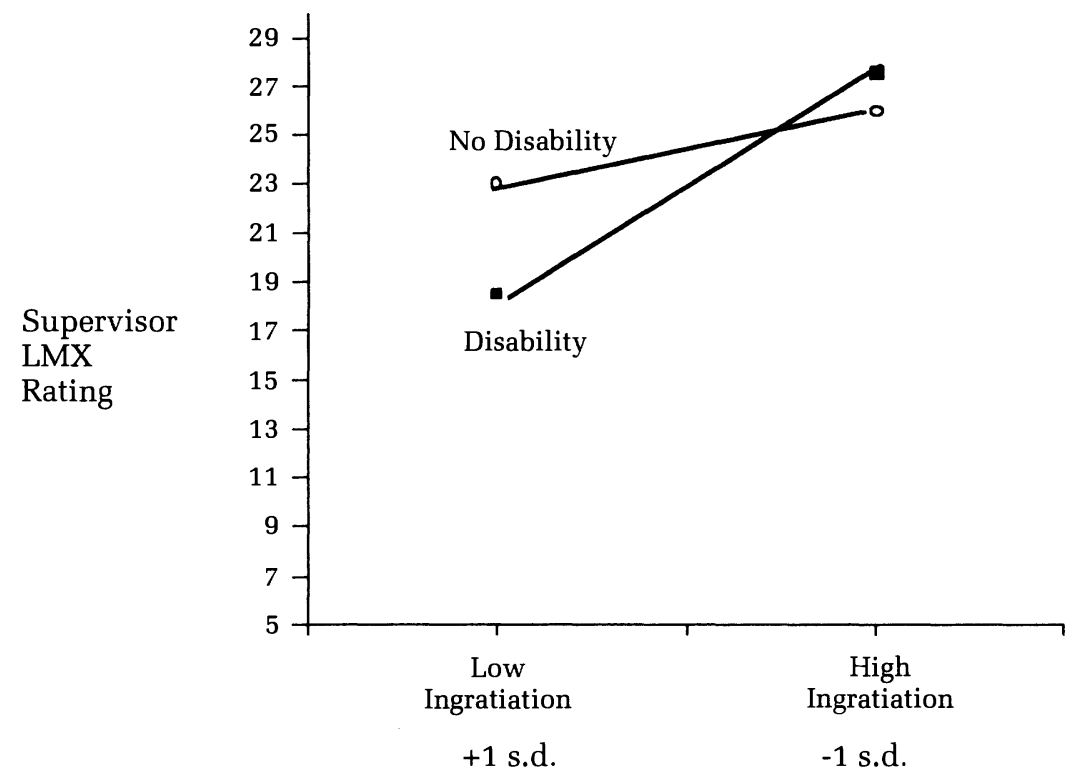

Ingratiation

rating for the nondisabled (23.67). Thus, it appears that ingratiation mitigated the negative effects of disability but did not result in positive amplification.

In order to explore whether some forms of ingratiation had stronger effects than others, we did the hierarchical regression test reported in Table 3 again, calculating a separate equation for each subscale of the ingratiation measure: self-presentation (four items, $\alpha=.85$ ), other enhancement (seven items, $\alpha=.91$ ), opinion conformity (seven items, $\alpha=.89$ ), and favor rendering (six items, $\alpha=.89$ ). For each of these four equations, the results of the analyses using the total ingratiation scale were replicated, in that there were significant disability and ingratiation main effects, and a significant interaction between disability and the specific type of ingratiation. Total multiple squared correlation coefficients $\left(R^{2} s\right)$ all exceeded .19, with the exception of the one indicated when self-presentation was the independent variable $\left(R^{2}=.14\right)$. Interactions involving self-presentation and rendering favors increased the variance accounted for by 2.4 percent and 2.1 percent, respectively. Interactions involving other enhancement and opinion conformity had effect sizes more in line with the total scale because they increased the variance accounted for by 4.2 percent and 3.9 percent, respectively. We also tested a model that simultaneously included all four individual ingratiation strategies and their interactions with disabilities. This model accounted for 22 percent of the variance in LMX ratings
( $F=3.54, p<.001$ ), compared to 21 percent for the model using the aggregated ingratiation measure. The only significant individual effect in this model was for the rendering favors strategy. This finding was a result of multicollinearity problems, because the correlations among the four types of ingratiation ranged from .77 to .94 . Specific results of these analyses are available from the first author.

\section{OVERALL DISCUSSION}

In both our simulation experiment and our correlational field study, we found that disability and ingratiation interacted to influence supervisors' ratings of LMX quality and that ingratiation was more strongly related to LMX quality for subordinates with disabilities. What differed between the studies was the relative ratings of those demonstrating high and low ingratiation behavior. In the simulation study, positive bias toward subordinates with disabilities was found when they engaged in ingratiation behavior. When there was no ingratiation, there was no disability effect. However, in the field study, the subordinates with disabilities and high ingratiation scores received LMX ratings similar to those the nondisabled subordinates with high ingratiation scores received. When ingratiation ratings were low, subordinates with disabilities received significantly lower LMX ratings, indicating negative bias. Indeed, when ingratiation was controlled, there was a negative main effect for disability. Thus, although both studies suggested ingrati- 
ation was more important for subordinates with disabilities, negative bias was only found in the field setting.

These findings raise several issues. First, it was clear in both studies that engaging in ingratiation behavior made more of a difference for disabled subordinates than it did for nondisabled subordinates. This finding supports the ambivalence response amplification hypothesis (Katz \& Glass, 1979). This issue is also important to the LMX literature because it stipulates that personal characteristics such as disability interact with behaviors (such as ingratiation) to influence LMX relationships. Personal characteristics have only been previously postulated to have main effects on LMX (cf. Dienesch \& Liden, 1986). Whether other personal characteristics, like sex or race, interact with various behaviors to influence LMX relationships is a question for future research. The ambivalence response theory suggests that they will do so, as long as the characteristic is considered as a source of stigma and disadvantage. What our findings do suggest is that future research examining the effects of personal characteristics on LMX relationships should also address how these characteristics interact with certain behaviors.

Second, results from our supplementary analyses of specific types of ingratiation in the field study also suggest that some types of behavior (in this case, self-presentation ingratiation tactics) may have weaker effects than others. This finding coincides with other research that has shown that self-focused influence tactics have little or no effect on supervisory reactions, but that tactics focusing on supervisors, including expressions of opinion similarity, rendering favors, and other enhancement, are more effective (Wayne \& Liden, 1995; Wayne et al., 1997). Future research in this area should aim at creating an expanded framework for examining behaviors that may result in amplification effects.

The practical implication of these findings is clear: It is more important for people with disabilities to engage in upward influence tactics than it is for others. The field results suggest that subordinates with disabilities engaged in more ingratiation than did other subordinates. This finding is in line with anecdotal accounts of social relationships involving people with disabilities that stress that these individuals must take it upon themselves to make others comfortable and initiate interaction (Jones et al., 1984). Perhaps our research participants, who were in a competitive work environment, had learned to engage in these behaviors as a method of dealing with potential avoidance or bias.
These results suggest that subordinates can mitigate negative bias due to their disability by engaging in certain behaviors.

Finally, there is the question of why there was positive bias in the simulation study and negative bias in the field study, when essentially the same phenomena were being studied. It has been argued that when research concerning reactions to persons with disabilities is personally irrelevant to reactors, social desirability or general sympathy effects will emerge (e.g., Colella et al., 1998; Gibbons et al., 1980; Stone, Stone, \& Dipboye, 1992). This argument may explain why negative bias was only displayed in the field study. Our finding should serve as a caution for researchers doing work in this area whose research designs involve social interactions having little consequence or personal relevance to the participants. In future studies, researchers should also examine the effect of involvement by varying it (cf. Colella et al., 1998).

The problems with the simulation study were outlined above. The field study was an attempt to overcome some of those problems, but at the expense of giving up some confidence in internal validity and the direction of causal relationships. The convergence of the field and simulation results should ease these concerns. However, longitudinal work on this issue is still warranted to address the issue of the development of LMX relationships and causality. Although power in the field study was relatively low, owing to the small number of subordinates with disabilities, we found significant results.

Another concern is that the type of disability varied. Given the design of our study and the small sample, it was impossible to break analyses down by different types of disability. Given that people react more negatively to some disabilities than to others (see Stone \& Colella, 1996), being able to control for disability type would have probably led to cleaner or stronger findings. It would have also allowed for tests of hypotheses regarding the effects of different disabilities.

In conclusion, in this research we used both the leader-member exchange and the ambivalence response amplification conceptual frameworks to understand how a subordinate's disability may be related to the type of relationship he or she forms with a supervisor. More research needs to be done along these lines, especially in real workplace settings. In addition to examining this issue from an organizational perspective, such research could also inform work on counseling and training for people with disabilities. 


\section{REFERENCES}

Bauer, T. N., \& Green, S. G. 1996. Development of leadermember exchange: A longitudinal test. Academy of Management Journal, 39: 1538-1567.

Blanck, P. D. 1997. The economics of employment provisions of the Americans with Disabilities Act: Part I-Workplace accommodations. DePaul Law Review, 46: 877-914.

Byrne, D. 1971. The attraction paradigm. New York: Academic Press.

Carver, C. S., Glass, D. C., Snyder, M. L., \& Katz, I. 1977. Favorable evaluation of stigmatized others. Personality and Social Psychology Bulletin, 3: 232-235.

Colella, A. 1996. Organizational socialization of newcomers with disabilities: A framework for future research. In G. R. Ferris (Ed.), Research in personnel and human resources management, vol. 14: 351417. Greenwich, CT: JAI Press.

Colella, A., DeNisi, A. S., \& Varma, A. 1998. The impact of ratee's disability on performance judgments and choice as partner: The role of disability-job fit stereotypes and interdependence of rewards. Journal of Applied Psychology, 83: 102-111.

Dansereau, F., Alutto, J. A., \& Yammarino, F. J. 1984. Theory testing in organizational behavior: The varient approach. Englewood Cliffs, NJ: PrenticeHall.

Dansereau, F., Graen, G., \& Haga, W. J. 1975. A vertical dyad linkage approach to leadership within formal organizations-A longitudinal investigation of the role making process. Organizational Behavior and Human Performance, 13: 46-78.

Dienesch, R. M. S., \& Liden, R. C. 1986. Leader-member exchange model of leadership: A critique and further development. Academy of Management Review, 11: 618-634.

Engle, E. E., \& Lord, R. G. 1997. Implicit theories, selfschemas, and leader-member exchange. Academy of Management Journal, 40: 988-1010.

Fichten, C. S., \& Amstel, R. 1986. Trait attributions about college students with a physical disability: Circumplex analyses and methodological issues. Journal of Applied Social Psychology, 16: 47-51.

Fine, M., \& Asch, A. 1988. Disability beyond stigma: Social interactions, discrimination, and activism. Journal of Social Issues, 44: 3-21.

Gates, L. B. 1993. The role of supervisor in successful adjustment to work with a disabling condition: Issues for disability policy and practice. Journal of Occupational Rehabilitation, 3: 179-194.

Gibbons, F. X., Stephan, W. G., Stephenson, B., \& Petty, R. C. 1980. Reactions to stigmatized others: Response amplification vs. sympathy. Journal of Experimental Social Psychology, 16: 591-605.
Goffman, E. 1963. Stigma. Englewood Cliffs, NJ: Prentice-Hall.

Graen, G. 1976. Role making processes within complex organizations. In M. D. Dunette (Ed.), Handbook of industrial and organizational psychology: 12011245. Chicago: Rand McNally.

Graen, G., \& Cashman, J. 1975. A role-making model of leadership in formal organizations: A developmental approach. In J. Hunt \& L. Larson (Eds.), Leadership frontiers: 143-165. Kent, OH: Kent State University Press.

Hastorf, A. H., Northcraft, G. B., \& Picciotto, S. 1979. Helping the handicapped: How realistic is the performance feedback received by the physically handicapped? Personality and Social Psychology Bulletin, 5: 373-376.

Huston, T. L., \& Levinger, G. 1978. Interpersonal attraction and relationships. In M. R. Rosenzweig \& L. W. Porter (Eds.), Annual review of psychology, vol. 29: 115-156. Palo Alto, CA: Annual Reviews.

Jackson, S. E., Brett, J. F., Sessa, V. I., Cooper, D. M., Julin, J. A., \& Peyronnin. 1991. Some differences make a difference: Individual dissimilarity and group heterogeneity as correlates of recruitment, promotions, and turnover. Journal of Applied Psychology, 76: 675-689.

Jones, E., \& Wortman, C. 1973. Ingratiation: An attributional approach. Morristown: General Learning Press.

Jones, E., Farina, A., Hastorf, A., Markus, H., Miller, D., Scott, R., \& de Sales-French, R. 1984. Social stigma: The psychology of marked relationships. San Francisco: W.H. Freeman.

Katz, I., \& Glass, D. C. 1979. An ambivalence amplification theory of behavior toward the stigmatized. In W. Austin \& S. Worchel (Eds.), The social psychology of intergroup relations: 55-70. Monterey, CA: Brooks-Cole.

Klimoski, R., \& Donahue, L. 1997. HR strategies for integrating individuals with disabilities into the work place. Human Resource Management Review, 7: 109-138.

Kumar, K., \& Beyerlein, M. 1991. Construction and validation of an instrument for measuring ingratiatory behaviors in organizational settings. Journal of Applied Psychology, 76: 619-627.

Lerner, M. J. 1980. The belief in a just world: A fundamental delusion. New York: Plenum Press.

Liden, R. C., \& Graen, G. 1980. Generalizability of the vertical dyad linkage model of leadership. Academy of Management Journal, 23: 451-465.

Liden, R. C., \& Maslyn, J. M. 1998. Multi-dimensionality of leader-member exchange: An empirical assessment through scale development. Journal of Management, 24: 43-72.

Liden, R. C., Sparrowe, R. T., \& Wayne, S. J. 1997. Leader- 
member exchange theory: The past and potential for the future. In G. R. Ferris (Ed.), Research in personnel and human resource management, vol. 15: 47119. Greenwich, CT: JAI Press.

Liden, R. C., Wayne, S. J., \& Stilwell, D. 1993. A longitudinal study on the early development of leadermember exchanges. Journal of Applied Psychology, 78: 662-674.

Scandura, T., \& Graen, G. 1984. Moderating effects of initial leader-member exchange status on the effects of leadership intervention. Journal of Applied Psychology, 69: 428-436.

Scandura, T., Graen, G., \& Novak, M. 1986. When managers decide not to decide autocratically: An investigation of leader-member exchange and decision influence. Journal of Applied Psychology, 71: 579584 .

Stone, D. L., \& Colella, A. 1996. A model of factors affecting the treatment of disabled individuals in organizations. Academy of Management Review, 21: $352-401$.

Stone, D. L., \& Michaels, C. 1994. Effects of nature of the disability and competitiveness of the reward system on selection of disabled team members. Paper presented at the annual meeting of the Academy of Management, Dallas.

Stone, E. F., Stone, D. L., \& Dipboye, R. L. 1992. Stigmas in organizations: Race, handicaps, and physical unattractiveness. In K. Kelly (Ed.), Issues, theory, and research in industrial and organizational psychology: 385-457. New York: Elsevier Science.

$\rightarrow$ Tsui, A. S., \& O'Reilly, C. A. 1989. Beyond simple demographic effects: The importance of relational demography in superior-subordinate dyads. Academy of Management Journal, 32: 402-423.

Turban, D. B., \& Jones, A. P. 1988. Supervisor-subordinate similarity: Types, effects, and mechanisms. Journal of Applied Psychology, 73: 228-234.
Wayne, S. J., \& Ferris, G. R. 1990. Influence tactics, affect, and exchange quality in supervisor-subordinate interactions: A laboratory experiment and field study. Journal of Applied Psychology, 75: 487-499.

Wayne, S. J., \& Green, S. A. 1993. The effects of leadermember exchange on employee citizenship and impression management behavior. Human Relations, 46: 1431-1440.

Wayne, S. J., \& Liden, R. C. 1995. Effects of impression management on performance ratings: A longitudinal study. Academy of Management Journal, 38: 232260.

Wayne, S. J., Liden, R. C., Graf, I. K., \& Ferris, G. R. 1997. The role of upward influence tactics in human resource decisions. Personnel Psychology, 50: 9791006.

Wortman, C. B., \& Linsenmeier, J. A. W. 1977. Interpersonal attraction and techniques of ingratiation in organizational settings. In B. Staw \& G. Salancik (Eds.), New directions in organizational behavior: 133-178. Chicago: St. Clair.

Yammarino, F. J., \& Markham, S. E. 1992. On the application of within and between analysis: Are absence and affect really group-based phenomena? Journal of Applied Psychology, 77: 168-176.

Adrienne Colella received her Ph.D. from the Ohio State University. She is currently an associate professor of management at Texas A\&M University. Her research interests include work treatment issues involving employees with disabilities, employee accommodation, and organizational socialization.

Arup Varma received his Ph.D. from Rutgers University. $\mathrm{He}$ is currently an associate professor at the Institute of Human Resources and Industrial Relations at Loyola University, Chicago. His research interests include topics in performance appraisal, issues related to the treatment of individuals with disabilities, and high-performance work systems. 